\title{
PREVENT, safeguarding and the common-sensing of social work in the United Kingdom
}

\author{
David McKendrick ${ }^{1}$ and Jo Finch ${ }^{2}$
}

${ }^{1}$ Glasgow Caledonian University, Scotland

${ }^{2}$ University of East London, England
AOTEAROA

NEW ZEALAND SOCIAL WORK 31(2), 18-28.

CORRESPONDENCE TO: David McKendrick david.mckendrick@gcu.ac.uk

\begin{abstract}
INTRODUCTION: The Counter-Terrorism and Security Act (2015) passed in the United Kingdom (UK) made it mandatory for social workers, as well as a wide range of caring professionals, to work within the PREVENT policy, originally introduced in 2002 , as one strand of the UK's overall counter-terrorism policy.

METHOD: The paper offers a theoretical account of how complex issues, like terrorism, that understandably impact on the safety and security of countries, are reduced to a series of assertions, claims and panics that centre on the notion of common sense.

IMPLICATIONS: We theorise the concept of common sense and argue that such rhetorical devices have become part of the narrative that surrounds the PREVENT agenda in the UK, which co-opts social workers (and other public servants) into an increasingly securitised environment within the state. In other words, the appeal to common sense stifles critical debate, makes it hard to raise concerns and positions debates in a binary manner. We use the example of how there has been a decisive linking of traditional safeguarding social work practice with counter-terrorism activity.
\end{abstract}

CONCLUSIONS: We posit that linkages such as this serve to advance a more closed society, resulting in a "chilling" of free speech, an increase in surveillance and the unchecked advancement of a neoliberal political agenda which promotes economic considerations over issues of social justice. This we argue, has implications for not only the UK, but for other countries where social workers are increasingly being tasked with counter-terrorism activities.

KEYWORDS: safeguarding; counter-terrorism; social work; PREVENT

We wrote a very early version of this paper in the aftermath of a terrorist attack on the UK's Houses of Parliament in March 2017, during which a policeman and four tourists tragically lost their lives. A lone attacker drove down Westminster Bridge, running people over before stabbing a policeman at the gates at the House of Parliament. We recall this event all too well, as well as previous terrorist attacks in the UK, namely the 2005, 7 July bombings in London, whereby 52 people lost their lives and over 700 were injured. Other terrorist attacks in the UK include the 2007 Glasgow airport attack, whereby a car filled with explosives was rammed into the doors of the main terminal; the London Bridge terrorist attack in 2018, where eight people died; and the Manchester Arena attack a few months later, whereby a lone attacker detonated a bomb that killed 22 people, some of whom were young fans of Ariana Grande who was 
playing in concert that night. These were, and still are, difficult to understand and process for citizens and rightly cause fear and anxiety. Indeed, as residents of London and Glasgow, we share those continued anxieties about our safety and, like any other citizens, are broadly in favour of counterterrorism measures to ensure that those who wish to do harm in the name of religion or politics, are rightfully prevented from carrying out devastating terrorist attacks.

What we increasingly note, however, are what we describe as thin and common-sense narratives that often dominate discussion about terrorism and how to prevent terrorism. Alongside this, such commonsense narratives have also crept into social work policy and practice in the UK. We set about here to interrogate the UK's counterterrorism policy, PREVENT, as a prime example of a common-sense narrative, and the detrimental impact this has on social work in particular. Accordingly, we critically explore PREVENT, by drawing on the works of Italian political philosopher, Antonio Gramsci, utilising his concepts of hegemony and common sense that are central to his thinking. Using the theoretical proviso of common-sense narratives, we will explore how the anxiety around terrorism and violent extremism, mobilises thin discourses that advance the aims of the neoliberal project embodied in Britain by the current government while, at the same time, eroding a desire for a more egalitarian society characterised by a more equal distribution of wealth and greater equality.

Our key aim is to critically consider how such counter-terrorism policies may serve to reframe, and reduce the role and emancipatory tasks of social workers, while developing a new professional reality for social work driven by securitisation and surveillance, rather than traditional social work values of empowerment, liberation and conscientization. We will argue that social work professionals in UK and other Western democracies are increasingly being deployed as agents of state securitisation. We will explore the surreptitious methods by which this is facilitated and the ways in which policy and practice deploy series of objects, images and linguistic devices to promote a sense of global insecurity (Massumi, 2015) which restricts traditional sites for the development of empowering narratives central to social work practice. The article begins with a brief overview of the UK's PREVENT policy in order to contextualise subsequent theoretical explorations.

\section{PREVENT}

In the aftermath of the $9 / 11$ terrorist attack in the USA, many Western democracies, including the UK, subsequently revised their counter-terrorism policies. The UK's overall counter-terrorism policy, known as CONTEST was introduced in 2003, with further amendments in 2009, 2011 and 2018. CONTEST covers what has become known as the "Four P's": Prevent, Pursue, Protect and Prepare. The PREVENT policy aims at, firstly, identifying those at risk of or suspected of extremism and radicalisation and, secondly, preventing people being drawn into terrorism. The Government's definition of extremism is as follows:

Vocal or active oppositions to fundamental British Values, including democracy, the rule of law, individual liberty and mutual respect and tolerance of different faith and beliefs. We also include in our definition of extremism, calls for the death of members of our armed forces, whether in this country or overseas. (HM Government, 2014)

And radicalisation is defined as the:

...process by which a person comes to support terrorism and forms of extremism leading to terrorism, committing terrorist acts either abroad or on home ground. (HM Government, 2014)

The PREVENT policy, however, was ramped up significantly when in July 2015, The Counter-Terrorism and Security Act (2015) 
came into force in the UK. This requires a number of specified agencies, including schools, colleges, prisons, local authorities, and higher education establishments to actively promote "British values" (McKendrick \& Finch, 2016). It also places a legal duty on such professionals to work within the PREVENT agenda. In other words, such practitioners must now identify and report those deemed to be at risk of extremism and terrorism, possibly work with security services to assess the level of risk, and, provide services if required.

For social workers, now under a statutory obligation to work within the PREVENT agenda, this poses distinct ethical challenge, not least of which is being caught up so decisively in the state's security apparatus (Finch \& McKendrick, 2015). We also note the co-opting of the term "safeguarding" within the PREVENT agenda which, in our view, deliberately attempts to frame such social work interventions in a benevolent, simplistic and common-sense manner. We now move on to consider the meaning of common sense, and how, a benign and everyday word is increasingly cynically and worryingly applied in complex social policy spheres.

\section{Gramsci and common sense}

The call for a common-sense approach is a familiar rallying cry from a range of neoliberal actors. For example, when Michael Gove was the UK Secretary of State in 2012, while extolling the virtues of early interventions in Children and Families work and the positive influence this could have on placing children for adoption, he called for social workers to deploy a common-sense approach to the issue of inter-racial adoption by placing black children with white families (UK Government, 2012). Further examples of politicians extolling the need for common sense include Boris Johnson who, in the BREXIT campaign, excused his own racist attitudes by suggesting it was common sense to feel afraid seeing a group of black youths when out running (Jeffries, 2016).
Former UK Prime Minister, David Cameron, regularly invoked the notion of common sense in his speeches. For example, on one occasion urging social workers to use common sense when dealing with suspected cases of child abuse (Holeman, 2015) and in relation to Ashya King, a seriously ill child who was removed from hospital and taken abroad by his parents (against doctors' advice), Cameron called for an "urgent outbreak of common-sense" (More-Briger, 2014). Indeed, the common-sense rhetoric continues with Iain Duncan-Smith, referring to, at the time of writing, then current Prime Minister Theresa May's remark about the need for tighter immigration controls after the Westminster attack as common sense (BBC News, 2017).

The deployment of this particular phrase seems to indicate that there is some kind of sense that is held in common, an immutable, obvious, simple sense that is so obvious to everyone that it does not require description, qualification or explanation. Common sense in this particular idiom, suggests a set of ideals and values that are so recognisable, non-controversial, and straightforward, so widely shared and accepted, that there is no other realistic, viable alternative. The point of view described as common sense, is just so obvious and irrefutably true. Further, one who does recognise or deviates from this common-sense view, must be considered a potential risk to society. We suggest, however, that the concept of common sense needs urgent attention and critical analysis, because of its profligate and indiscriminate use in social work and other policy arenas.

A critique of the concept of common sense is offered by Gramsci (1973). He describes common sense as a linguistic device used to support the existence of hegemony. Gramsci (1973) describes hegemony as the state of being where powerful elites, the state or juridical government, exercise "direct domination or command" (1973, p. 12) over the population, or as Gramsci referred to them, "subalterns" (1973, p. 12). Common sense is deployed by elites therefore, as a 
disciplinary vehicle to ensure their position of power remains unchallenged, hence allowing it to remain secure and to be expanded. Subalterns are viewed with a sense of disdain and are seen as unlikely to challenge the ideas being suggested as they are delivered by those in power. To further maintain this hegemony, the development of a sense of "feeling as opposed to knowing" (1973, p. 418) is vital; hegemony requires a domination of the media and other methods of communication by those in power. Further, matters pertaining to national security are presented, using a performative narrative which utilises iconic imagery.

If we relate this to events in London, immediately following the March 2017 attack on Westminster Bridge and the Houses of Parliament referred to at the outset of this paper, images of the Houses of Parliament, Big Ben and red London buses were frequently deployed, while Parliament itself was described as the "cradle of democracy" by many news outlets in the UK and beyond. We noted that references to the Blitz were frequent, and the indomitable spirit of Londoners was a common theme across the reporting of the event (see for example, The Daily Mirror, 2017). While to some extent accurate (indeed, one of the authors of this paper who resides in London, was rather defiantly making statements of getting on with it and not being afraid when travelling on the London transport system the following day), such responses can also be seen as what Mayo (2008) describes as "distorted and fragmentary" (Mayo, 2008, p. 430) deliberately amplifying cultural references that evoke familiar and powerful remembrances, emphasising Britain as an island nation proud of its independence and resilience. These versions of events are mobilised and reinforced by powerful intellectuals and actors, including for example, the Mayor of London, Sadiq Khan, who proclaimed that the events were "an attack on the very heart of our democracy and the symbols of the values we cherish so much..." (UK Government, 2017).
Gramsci described such processes as "diffuse uncoordinated features of a general form of thought common to a particular period and a particular popular environment" (1973, p. 300). In the case of the London attack, the reinforcement of hegemonic power through cultural iconography supports a narrative of resilience and stoicism, simultaneously providing reassurance while reinforcing a familiar uniqueness of British life. As a device, this set of linguistic and cultural references are deliberately deployed to reinforce to subalterns that hegemonic power is retaining control despite the reality of the current crisis and the threat of future attacks. A feature of hegemony is its control over the media and its ability to manage and co-ordinate a clear message which maintains the imbalance between hegemony and the subaltern masses. It is of interest to note that the development of social media has been a site of concern for the hegemony as it struggles to develop a means of control over a diffuse and novel method of communication. Whilst, in the context of a sustained series of terrorist attacks this may be understandable, it can also in the current circumstances, be seen as a retrenchment of privacy for all and an opportunity for the government to advance its involvement in the private lives of its citizens. Policies such as PREVENT and its proponents, employ such "distorted and fragmentary" narratives, as well as bring about surveillance and securitisation creep, which will usher in the potential demise of traditionally caring and emancipatory professions.

\section{Common sense and neoliberalism}

In a more recent exploration of the politics of common sense, Hall and O'Shea (2015) describe it as:

... a form of "everyday thinking" which offers us frameworks of meaning with which to make sense of the world. It is a form of popular, easilyavailable knowledge which contains no complicated ideas, requires no sophisticated argument and does not 
depend on deep thought or wide reading. It works intuitively, without forethought or reflection. It is pragmatic and empirical, giving the illusion of arising directly from experience, reflecting only the realities of daily life and answering the needs of "the common people" for practical guidance and advice. (2015, p. 8)

In other words, common-sense explanations for complex world events for example, provide the populace with simple certainties. Equally, when politicians call for a commonsense approach, this has a resonance with the populace, who can intuitively, and very easily, without thought or reflection, grasp, understand and make sense of such everyday problems and on the surface, simple and seemingly effective solutions to these potentially anxiety-provoking issues. Thin narratives are thus effectively employed.

Hall and O'Shea (2015) argue that commonsense narratives have been deployed, for example, as a vehicle to obviate the effects of the profligate behaviour of bankers and venture capitalist which resulted in the financial crisis of 2007-2008 and, further, have been used as:

...an alibi for a far reaching and further restructuring of state and society along market lines with a raft of ideologically driven reform designed to advance privatisation and marketization. (2015, p. 11)

Furthermore, they contend that neoliberalism unfairly targets the most vulnerable in society in a process where the state bears the responsibility for the socialisation of debt accrued, while profits from this process (in the forms of bonuses for bankers gained as a result of the required restructuring following the crash) have been subsumed by private individuals or institutions. This has significant and worrying consequences for those who are experiencing vulnerability as public services suffer under the ideology of austerity. In real terms this sees brutal cuts to public service budgets resulting in significant losses to jobs and services.

The application of this form of common sense creates a doctrine of competitive individualism where the accrual of wealth and power is seen to be located in the strength of character of the individual; the familiar call for the unemployed to "get on their bike" to look for work voiced by former UK Conservative MP Norman Tebbit in the 1980s is rephrased and modernised into a strivers v skivers dichotomy favoured by Cameron and his former Chancellor of the Exchequer, George Osborne. In this febrile environment, the influence of wider political and social structures is ignored and those who are left behind in society are perceived as lacking in moral ability and courage. Standing (2011) argues that one result of this is that a new precariat class has emerged, one that is defined by mobility and its social and economic uncertainty. Referring to the neoliberal project, Standing (2011) states:

...it reveres competitiveness and celebrates unrestrained individual responsibility, with an antipathy to anything collective...The state's role is seen as primarily setting and strengthening the rule of law. But the law has never been minimalist, as some neoliberals depict it. It is intrusive and orientated towards curbing nonconformity and collective action. (2011, p. 132)

In brief, the neoliberal regime needs, despite protestations to the contrary, an intrusive and strong government to ensure its ideology flourishes. Standing (2011) sees a significant shift from collectivist postwar welfare regimes to one that sees those with wealth and power increasing their global reach and power while those in poverty experience greater risk, insecurity and precarity. We are making the argument therefore, that the continuing penetration of neoliberal ideology is supported by the hegemonic creation of a common sense that asserts that there is no other way or, as has 
been a long-standing popular Conservative politician refrain, originally popularised by former Chancellor of the Exchequer, George Osborne and then taken up by former Conservative Prime Minister, David Cameron, "we are all in this together" (see, for example, The Guardian, 2012).

In a Gramscian view, the oppressive nostrums of neoliberalism thus curtail an alternative from emerging, and a series of straw men are created to divert the subalterns' attention from the hegemony's continued dominance. So, as we argue, a threat of terrorism, and those who perpetrate it, diverts attention away from increasing curtailment of civil liberties, increased surveillance, securitisation creep and the demonisation of particular communities or faith groups, namely, Muslim communities who become in effect, "straw men" and are "othered".

Hall and O'Shea (2015) argue further that the state is travelling in an explicitly neoliberal direction, one which emphasises a free individual, engaging with others, without government interference, through market transactions, scaffolded by images, ideas and linguistic devices which, when taken together, represent the hegemonic notion of common sense which supports the permeation of neoliberalism into every aspect of our society. As it can be seen, traditional collectivist ideas embodied in the welfare state of collectivism, strength in unity and the power of working-class movements are diminished through the establishment of new common sense vocabularies described by Massey (2015) as:

...the vocabularies which have reclassified roles, identities, and relationships - of people, places and institutions - and the practice which enact[s] them embody and enforce the ideology of neoliberalism, and thus a new capitalist hegemony. $(2015$, p. 26$)$

Having established the relationship between hegemony, common sense and neoliberalism, we return to the PREVENT agenda and give consideration to the role PREVENT plays in operationalising what Gandy (1993) described as the panoptic sort, a method of social surveillance developed by marketing professionals to identify and classify people who can then be targeted for particular goods or services. We will develop the argument that a policy like PREVENT is a natural consequence of the furthering of the neoliberal agenda, utilising a securitising narrative to create a non-problematic and common-sense relationship between safeguarding and radicalisation.

\section{Safeguarding, securitisation and radicalisation}

Fergusson (2007) argues that recent developments in social work policy have seen a shift in the terrain, away from generalised notions of welfare towards more personalised approaches which see the individual as paramount. Fergusson (2007) argues that this comes about at the expense of more traditional social work notions that emphasise the centrality of structural issues that impact on the lives of individuals. He argues that this shift has supported the neoliberal tenet of the transfer of risk from the state to the individual, and, that this transfer is activated through policies such as personalisation. We would develop this further and suggest it can also be seen most decisively in policies like PREVENT. Giddens (1991) describes the concept of "ontological security" which is often used in international relations, and refers to a sense of mental stability that is derived from the security and familiarity of surroundings that can be challenged by chaotic, unpredictable and unexpected events. We advance the argument that, in the immediate aftermath of the Westminster attack, a similar set of events occurred which aimed to increase a sense of national ontological security; the apprehension and death of the attacker was an immediate action which eliminated the risk and the swift media led diffusion of iconic imagery, created a sense of familiarity which worked against the chaos of the attack. The use of iconic imagery by the 
media and the promotion of a wartime spirit was mobilised as an evocative set of images and ideas which provided a sense of national familiarity and supported the reinstitution of a feeling of calm.

Similarly, the development of PREVENT along familiar, and to some extent, social work, lines of safeguarding, provides both ontological security for practitioners and the general public alike and can be seen as related to a key neoliberal ideological underpinning, that of avoiding assigning responsibility to societal structures and deeply ingrained inequalities, but rather, emphasising the role of the individual. The term safeguarding was therefore decisively co-opted into policy pronouncements and the practices of PREVENT (Finch \& McKendrick, 2019). Social workers' (and other professionals') statutory duty to work with PREVENT was promoted as part of normal, everyday safeguarding procedures. Likewise, the promotion by UK politicians of the similarities between online sexual groomers and online radicalisers for example, allowed a familiar notion of wickedness mediated through the internet; the virtual predator hiding on the internet setting a carefully laid trap to entice vulnerable young people into their world where they can be exploited for the nefarious purposes of the paedophile/ radicaliser. While we are in no way seeking to undermine this as a reality, we are seeking to develop a more carefully considered and critical discussion around the issues that this exposes.

Ontological security depends, in no small way, on the establishment of a set of images, ideas and debates that the population can engage with in a way that is familiar, and therefore comfortable for them. It is our contention that there are significant differences between online radicalisation and online sexual exploitation. Primarily, those involved in online radicalisation would claim that they are motivated by religion, or a particular political ideology masked as religion, and a sense of political imperatives that relate in some way to the actions of Western colonialism. Online sexual exploitation does not exist in these dimensions; rather it relates to a desire for sexual and personal gratification that connects to a sense of power (or powerlessness). We strongly suggest that policies that seek to reduce online radicalisation and online grooming need to tread a careful path that ensures they take into account these subtle differences in application and motivation. An urgent need exists therefore, to ensure that policies such as PREVENT are subject to a rigorous academic and professional discussion, as well as empirical research, particularly given the sensitivity of the issues involved and the vulnerability of those whose lives are affected by them, to appreciate the similarities and perhaps, more importantly, highlight the differences in both of them. We have noted for example, the paucity of literature within social work in the UK about PREVENT with only ourselves, Stanley and Guru (2015), and Stanley, Guru, and Gupta (2018) exploring this from a theoretical standpoint.

PREVENT is a neoliberal policy that strongly emphasises the actions of individuals while downplaying the role of the state or other structural actors. To that end, its close relationship, and indeed, the deliberate adoption of traditionally welfarist social work terms such as safeguarding, should not allow for a situation where the issues are regarded as the same. As it stands, the current iteration of PREVENT with its emphasis on ontological security fits the safeguarding rhetoric perfectly, as it sees risk being constructed in intimate individual relationships and has little or no tangible connection with structural factors. This was recognised by Emerson (2016) in his role as Special Rapporteur on Terrorism when he observed that many states conceptualised radicalisation in an overly simplistic way that was:

...based on a simplistic understanding of the process as a fixed trajectory to violent extremism with identifiable markers along the way. (2016, p. 7) 
In other words, Emerson is arguing that the existing response to radicalisation lacks a depth of knowledge and understanding of the complexity of the issue at hand and so the resulting policies are unlikely to be the most effective method of intervention. Emerson (2016) goes on to say:

States have tended to focus on those [approaches] that are most appealing to them, shying away from the more complex issues, including political issues such as foreign policy and transnational conflicts. (2016, p. 7)

We concur with Emerson, as well as other academics for example, Kundani, (2015), Thomas, (2010) and Sabir (2017), that PREVENT is conceptually flawed, as it deliberately promotes an overly simplistic understanding of the complexity of the issue and, as we argue, deploys a common sense notion of "safeguarding as exactly the same as radicalisation" when they have, in our view, significant differences, most notably in the intrinsic motivation and indeed, agency, of those involved in the different activities. If we seek to impact the phenomena of radicalisation and online radicalisation then, we argue, that a Gramscian notion of "good sense" needs to be deployed, in that current responses are mired in the notion of "common sense".

Good sense requires recognition that, in a climate of panic where notions of ontological security are advanced, it is unlikely that the responses that are developed are well thought through and subject to discipline and rigour. The issue of radicalisation is thus multi-layered and presents in different ways in different individuals; however, in almost all cases, it is not solely located in the personal but has a significant connection with the political and structural (Kundani, 2015; Sabir, 2017). Developing a meaningful challenge requires a careful consideration of how the structures that currently exist are equipped to manage the challenges represented by the issue of radicalisation. We will now go on to consider the existing arrangements for countering violent extremism and offer some considerations of their motivation and their effectiveness.

\section{Countering violent extremism}

Buzan (1983) argues that the individual is an "irreducible basic unit to which security can be applied" (1983, p. 243) which dovetails with the notion of individual responsibility that Ferguson (2007) referred to. We contend that, in the tense social and political climate that emerges in the aftermath of a terrorist attack, the influence of external, structural factors such as the political environment or the dominance of a particular economic model is understated. The outcome of this is that (potentially) legitimate societal issues become pathologised as individualised responses, and are not fully taken into account. Simultaneously, a deliberate obscuring of the responsibility that should be borne by the oppressor occurs and sees the oppressor presenting themselves as a victim of an "evil" often coming in the form of a seemingly unsolicited attack on a vulnerable, innocent population.

We argue that PREVENT promotes exactly this set of circumstances as it conceptualises the actions of those it focuses on as located out with any sphere of societal responsibility. PREVENT thus promotes a perception of the pathologised individual and operates in a pre-criminal space which places a requirement on public service workers, such as librarians, nurses, teachers and social workers to be attuned to the threat of radicalisation and to be aware of the referral mechanisms for people whom they suspect of becoming radicalised. As documented earlier, and unsurprisingly, PREVENT has come in for extensive criticism, operating as it does in a moral and ethical dimension that is at odds with the basic tenets of most of the caring professions required for its operation.

The universalism that is at the heart of PREVENT blurs the professional distinctions between those on the "front line" (Coppock \& McGovern, 2014) of deradicalisation and 
presumes that all public servants have the skills and, indeed, the opportunities to detect the so called "signs and symptoms" of radicalisation. This approach reminds the authors of early child protection training which provided student social workers with images of injuries sustained by children often at the hands of their parents and carers, and then provided lists of the so called "signs and symptoms". This, while useful in an observational sense, is deeply personalised and did little to locate professionals in a place where they can challenge the social phenomenon of child protection. As the work of Featherstone, Morris, and White (2014), Parton (2014) and Garrett (2013) has identified, the issue of poverty is central to child protection, with such activity being more common in deprived environments. The "airbrushing" (McNicol, 2017) of structural factors from the gamut of professional responsibility of social workers paves the way for an increase in pathologised responses (such as signs of safety) as opposed to the development of a professional identity that sees social workers as agents of social change as well as agents of social control. Counter-radicalisation work offers a powerful example of the ascendance of pathologised responses that emphasise the personal over the impact of structural issues that are a result of the dominance of neoliberal ideology.

Social work exists in a demanding professional environment, external factors such as austerity and a national government that seems at odds with central tenets of social work activity such as collectivism and an awareness of geopolitical factors on the actions of individuals, are complicated by internal factors such as aggressive inspection regimes which have the power to remove social work activity from local government while ensuring that local government retains responsibility for any errors. Indeed, there exists a culture of moral hyper-regulation which sees professionals as "24/7" social workers (Banks, 2008; Petrie, 2009) required to uphold public trust and confidence in social work, the result of which is that social work and social workers are prevented from challenging neoliberalism or at least run the risk of referral to regulatory bodies should they do so on "competence" grounds.

\section{Conclusion}

We conclude by arguing that such securitised and so-called "common-sense" policies and practices are evidence of the increased prominence of neoliberalism in social work training, education and service delivery. As a result, significant importance is placed on the ontological security provided by a raft of performance measures, management information and recruitment and retention detail that are a cornerstone of the neoliberal project. These practices are introduced at the expense of ideas of the commons, public good, and the desire to see a better, more equal and fair society, all of which better accords with social work values in the UK, and as enshrined in the International Federation of Workers definition of the practices, purpose and values of social work.

We argue that current social work practices are becoming embodied by the common sensing of social work are a form of deliberate, premeditated, hegemonic activity designed to increase a sense of ontological security underpinned by a form of neoliberal governmentality. At its core, this approach places deliberate emphasis on activities, methods of training and intervention techniques that are exclusory, placing a deliberate over-emphasis on a pathologised, individuated set of responses that deploy a particular interpretation of the role of social workers as professionals who "work on" rather than "work with" families, as well as the significant turn to target individuals. The structural factors that play such a significant role are airbrushed out in favour of a set of responses motivated by new public management and the "performance dashboard" has obscured the belief in radical emancipatory politically motivated social work. We note that PREVENT and its associated practices are an acute example of such a decisive move, with the duty to 
safeguard, moving decisively away from a welfarist model, to one of securitised safeguarding.

\section{References}

Banks, S. (2008). Critical commentary: Social work ethics. British Journal of Social Work, 38, 1238-1249.

BBC News. (2017). Deportation remarks common-sense. Retrieved from http://www.bbc.co.uk/news/av/uk21491561/deportation-remarks-common-sense

Buzan, B. (1983). People, states, and fear. An agenda for international security studies in the post-cold war era. Colchester, UK: ECPR Press.

Coppock, V., \& McGovern, M. (2014). Dangerous minds? Deconstructing counter-terrorism discourse, radicalisation and the "psychological vulnerability" of Muslim children and young people in Britain. Children and Society, 28(3), 242-256.

Emmerson B. (2016). Report of the Special Rapporteur on the promotion and protection of human rights and fundamental freedoms while countering terrorism. Retrieved from https://documents-dds-ny.un.org/doc/ UNDOC/GEN/G16/088/68/PDF/ G1608868.pdf?OpenElement

Featherstone, B., Morris, K., \& White, S. (2014). A marriage made in hell: Early intervention meets child protection. British Journal of Social Work, 44(7), 1735-1749.

Ferguson, F. (2007). Increasing user choice or privatizing risk? The antinomies of personalization. British Journal of Social Work, 7(3), 387-403.

Finch, J., \& McKendrick, D. (2015). The non-linear war on social work in the UK: Extremism, radicalisation, troubled families and the recasting of "safeguarding." Retrieved from http://www.reimaginingsocialwork.nz/2015/07/ the-non-linear-war-on-social-work-in-the-uk-extremismradicalisation-troubled-families-and-the-recasting-ofsafeguarding/

Finch, J., \& McKendrick, D. (2019). Securitising social work: Counter terrorism, extremism and radicalisation. In S. Webb (Ed.), Routledge handbook of critical social work (pp. 244-255). London, UK: Routledge.

Gandy, O. H., Jr. (1993). The panoptic sort: A political economy of personal information. Critical studies in communication and in the cultural industries. Boulder, CO: Westview Press.

Garrett, P. M. (2013). Social work and social theory: Making connections. Bristol, UK: Policy Press.

Giddens, A. (1991). Modernity and self-identity. Self and society in the late modern age. Cambridge, UK: Polity Press.

Gramsci, A. (1973). Selections from the prison notebooks (Q. Hoare \& G. Nowell-Smith, Eds. \& Trans.). London, UK: Lawrence and Wishart. Retrieved from https://archive.org/stream/ AntonioGramsciSelectionsFromThePrisonNotebooks/ Antonio-Gramsci-Selections-from-the-PrisonNotebooks_djvu.txt

Guardian, The. (2012). George Osborne tells Tory Conference, We are all in this together [video]. Retrieved from https://www.theguardian.com/politics/video/2012/ oct/08/george-osborne-tory-conference-video
Hall, S., \& O'Shea. A. (2015). Common sense neoliberalism. In S. Hall, D. Massey, \& M. Rustin (Eds.), After neoliberalism? The Kilburn Manifesto Project (pp. 52-68). London, UK: Lawrence and Wishart.

Holeman, M. (2015). David Cameron: Social workers must use "common sense" to tackle child abuse - PM warns of child abuse "on an industrial scale." The Daily Telegraph. http://www.telegraph.co.uk/news/uknews/ law-and-order/11447851/David-Cameron-socialworkers-must-use-common-sense-to-tackle-childabuse.html

Jeffries, S. (2016). The writings of Gove and Boris reveal a chilling double act. The Guardian. Retrieved from https://www.theguardian.com/politics/2016/jun/21/writingmichael-gove-boris-johnson-reveal-chilling-double-actbrexit-leave

Kundani, A. (2015). The Muslims are coming: Islamophobia, extremism and the domestic war on terror. New York, NY: Verso.

Massey, D. (2015). Vocabularies of the economy. In S. Hall, D. Massey, \& M. Rustin (Eds.), After Neoliberalism? The Kilburn Manifesto Project (pp. 24-36). London, UK: Lawrence and Wishart.

Massumi, B. (2015). The politics of affect. Oxford, UK: Polity Press.

Mayo, P. (2008). Antonio Gramsci and his relevance for the education of adults. Educational Philosophy and Theory, 40(3), 418-435.

McKendrick, D., \& Finch, J. (2016). The common-sensing of social work in the UK. Retrieved from http://www. reimaginingsocialwork.nz/2016/03/the-common-sensingof-social-work-in-britain/

McNicol, A. (2017). Is tackling poverty no longer "core business" for social workers? Community Care Magazine. Retrieved from http://www.communitycare. co.uk/2017/03/15/tackling-poverty-longer-core-businesssocial-workers/

Mirror, The. (2017). Voice of The Mirror. When terror attacks our democracy it will never be allowed to win. Retrieved from http://www.mirror.co.uk/news/uk-news/voice-mirrorlondon-terror-attack-10080522

More-Bridger, B. (2014). David Cameron calls for "common sense" as Ashya King's parents plan to sue. Retrieved from http://www.standard.co.uk/news/uk/parents-ofashya-king-to-sue-hospital-and-police-over-crueltyclaims-9706118.html

Parton, N. (2014). Social work, child protection and politics: Some critical and constructive reflections. British Journal of Social Work, 44(7), 2042-2056.

Petrie, S. (2009). Are the international and national codes of ethics for social work in the UK as useful as a chocolate teapot? Journal of Social Work Values and Ethics, 6(2). Retrieved from http://www.socialworker.com/jswve/ content/blogcategory/21/68/

Sabir, R. (2017). Blurred lines and false dichotomies: Integrating counterinsurgency into the UK's domestic "war on terror." Critical Social Policy, 37(2), 202-224.

Standing. G. (2011). The precariat: A new dangerous class. London, UK: Bloomsbury.

Stanley, T., \& Guru, S. (2015). Childhood radicalisation risk: An emerging practice issue. Practice: Social Work in Action, 27(5), 353-366. 


\section{ORIGINAL RESEARCH}

\section{THEORETICAL RESEARCH}

Stanley, T., Guru, S., \& Gupta, A. (2018). Working with PREVENT: Social work options for cases of "radicalisation risk." Practice: Social Work in Action, 30(2), 131-146.

Thomas, P. (2010). Failed and friendless: The UK's preventing violent extremism programme. British Journal of Politics and International Relations, 12, 442-458.

UK Government. (2012). Michael Gove speech on adoption. Retrieved from https://www.gov.uk/government/ speeches/michael-gove-speech-on-adoption

UK Government. (2017). Mayor of London statements Westminster attack. Available from https://www. Iondon.gov.uk/about-us/mayor-london/mayor-londonstatements-westminster-attack 